\title{
EFICÁCIA DA SEPARAÇÃO JUDICIAL NO BRASIL: OS IMPACTOS DOS RECURSOS ESPECIAIS 1.247.098 E 1.431.370
}

\author{
Valéria Julião Silva Medina*
}

SUMÁRIO: Introdução; 1.1 O RESP 1.247.098-MS; 1.2 O voto vencedor; 1.3 O voto vencido; 2 O RESP 1.431.370-SP; 3 Divórcio x Separação; 4 Das espécies de separação no direito brasileiro; 4.1 Separação judicial; 4.2 Separação consensual; 4.3 Separação de fato; 4.4 Separação cautelar; 5 Efeitos processuais da separação após EC/66 e novo código de processo civil; 5.1 Ações de família; 5.2 Flexibilização procedimental; 5.3 Tutelas provisórias; 5.4 Colaboração processual; 6 Conclusão; Referências.

RESUMO: A Emenda Constitucional 66/2010 permitiu a realização do divórcio direto, sem a necessidade de qualquer prazo e/ou discussão de culpa, suprimindo de forma velada o instituto da separação, que se tornou obsoleto. No entanto, com o advento do novo Código de Processo Civil, que manteve sua existência, mencionando-o em diversos dispositivos, sua viabilidade processual voltou a ser objeto de análise junto ao Superior Tribunal de Justiça que em duas oportunidades, nos julgamentos dos precedentes em voga, no ano de 2017, firmou entendimento no sentido de ratificar sua permanência no ordenamento pátrio. Neste sentido, serão sugeridas diversas soluções pragmáticas, à luz da nova lei, que deverão servir como código de conduta dos magistrados quando se defrontarem com as ações de separação judicial propostas com base neste entendimento, não se permitindo sua rejeição, de modo a garantir a estabilidade, a coerência e a integridade do sistema jurídico. Para o desenvolvimento da pesquisa utilizou-se o método monográfico e a técnica bibliográfica, documental e empírica.

PALAVRAS-CHAVE: Precedentes; Separação judicial; Efeitos; Novo CPC.

\section{EFFICACIOUSNESS OF JURIDICAL SEPARATION IN BRAZIL: IMPACTS OF SPECIAL APPEALS 1.247.098 AND 1.431.370}

ABSTRACT: Constitutional amendment 66/2000 allowed direct divorce, without the need for grace period and/or discussion on blame. It suppressed covertly the separation institution and made it obsolete. However, through its maintenance and men-

Advogada. Doutora em Direito Público pela Universidade Estácio de Sá (UNESA-RJ). Docente no curso de Direito Processual Civil e Prática Jurídica na Unifamma, Maringá (PR), Brasil.

E-mail:vjsmedina@yahoo.com.br 
tion in several dispositions after the introduction of the new Code of Civil Process, its procedural viability was once again the object of analysis by the Higher Court of Justice. At two opportunities, or rather, in judgments of precedents in 2017, the latter ratified its permanence in Brazilian law. From the point of view of the new law, several pragmatic solutions will be suggested, forming the judges' conduct code when they have to cope with suits involving juridical separation based on this interpretation. Since refusal is not permitted, stability, coherence and the integrity of the juridical system are guaranteed. Technical, documental and empirical bibliography will be employed to develop current research.

KEY WORDS: Precedents; Juridical separation; Effects; The new CPC.

\section{EFICACIA DE LA SEPARACIÓN JUDICIAL EN BRASIL: LOS IMPACTOS DE LOS RECURSOS ESPECIALES 1.247.098 Y 1.431.370}

RESUMEN: La Emenda Constitucional 66/2010 permitió la realización del divorcio directo, sin la necesidad de cualquier plazo y/o discusión de culpa, suprimiendo de forma velada el instituto de la separación, que se volvió obsoleto. Sin embargo, con la llegada del nuevo Código de Proceso Civil, que mantuvo su existencia, mencionándolo en diversos dispositivos, su viabilidad procesual volvió a ser objeto de análisis junto al Superior Tribunal de Justicia que, en dos oportunidades, en los juzgamientos de los precedentes en boga, en el año de 2017, firmó entendimiento en el sentido de ratificar su permanencia en el ordenamiento patrio. En este sentido, serán sugeridas diversas soluciones pragmáticas, a la luz de la nueva ley, que deberán servir como código de conducta de los magistrados cuando enfrentarse con las acciones de separación judicial propuestas con base en este entendimiento, no se permitiendo su rechazo, de modo a garantizar la estabilidad, la coherencia y la integridad del sistema jurídico. Para el desarrollo de la investigación se utilizó el método monográfico y la técnica bibliográfica, documental y empírica.

PALABRAS CLAVE: Precedentes; Separación judicial; Efectos; Nuevo CPC.

\section{INTRODUÇÃO}

Com o advento da EC 66, em 2010, travou-se um grande debate em sede doutrinária e jurisprudencial acerca da manutenção ou não do instituto da separação judicial no Brasil, o que gerava inequívocas controvérsias. O Superior Tribu- 
nal de Justiça em duas ocasiões distintas, nos julgamentos dos recursos especiais 1.247 .098 e 1.431 .370 , enfrentou a problemática e firmou posicionamento acerca de sua admissibilidade no ordenamento pátrio.

No primeiro caso sub examem, o REsp 1.247.098, julgado em 14/03/2017, originou-se em decorrência do ajuizamento de uma ação de separação consensual, em que os interessados pretendiam a homologação judicial das condições pactuadas entre eles, no tocante ao recebimento de pensão, regulação de visitas do único filho menor, bem como partilha e nome do cônjuge virago.

Após a distribuição da demanda, o magistrado de primeiro grau de jurisdição, determinou que adequassem a petição inicial, no prazo de dez dias, sob o argumento de que a aludida emenda constitucional havia "abolido" o instituto da separação judicial no Brasil, hipótese em que não poderia ser recebida.

Inconformados, os requerentes interpuseram o competente recurso de agravo de instrumento, então denegado monocraticamente, sendo confirmado pelo colegiado no julgamento do agravo interno. Deste acórdão, desafiaram o recurso especial com fundamento na negativa de vigência aos artigos 1.571, III, 1.572 e seguintes, todos do Código Civil, deduzindo, em síntese, que a EC 66/10 não extinguiu o instituto da separação no Brasil, o que justificou o juízo positivo de admissibilidade junto ao tribunal de origem.

Alguns meses depois, no julgamento do REsp 1.431.370, em 15/08/2017, a Colenda Corte Superior enfrentou a mesma problemática, sendo certo que nesta hipótese decorria a controvérsia no indeferimento do pedido de conversão da separação em divórcio, formulado judicialmente.

A peculiaridade desta demanda concentrou-se em situação diversa da anterior, pelo fato de que o juízo de primeiro grau recebeu o pedido de separação e determinou o prosseguimento do feito, após a devida tentativa de conversão do procedimento em divórcio, o que foi recusada por uma das partes. A aludida decisão foi objeto de agravo de instrumento e mantida pelo Tribunal de Justiça, sob entendimento de que a EC 66/2010 não havia abolido o instituto da separação judicial, porquanto não regulada pelo texto constitucional, mas sim por legislação ordinária.

$O$ vencido interpôs o recurso especial sob o argumento de que a aludida decisão do Tribunal de Justiça de São Paulo era divergente de outros Tribunais do país, o que justificou a admissão, sendo encaminhado ao Superior Tribunal de Justiça que ratificou a decisão anterior.

Considerando o destaque e relevância da matéria é que se fará uma análi- 
se pormenorizada dos julgamentos e seus efeitos jurídicos processuais e materiais, trazendo a lume as peculiaridades do instituto da separação judicial e suas diversas acepções no ordenamento pátrio.

Quanto à metodologia, foi utilizado o método de abordagem indutivo, partindo-se dos casos concretos examinados para alcançar uma generalidade, a ser utilizada como premissa nos demais casos a serem julgados pelo Poder Judiciário Brasileiro. Quanto ao método de procedimento empregado, o monográfico, sendo certo que a técnica de pesquisa utilizada foi a bibliográfica, a documental e a empírica.

A presente pesquisa foi dividida em cinco capítulos. Nos dois primeiros serão abordadas análises de cada um dos precedentes em voga; no terceiro, as diferenças substanciais entre o divórcio e a separação; no quarto, as espécies de separação existentes no ordenamento pátrio e, no quinto e último capítulo, serão trazidas diversas soluções pragmáticas, à luz do novo Código de Processo Civil (CPC), que deverão servir como código de conduta dos magistrados quando se defrontarem com as ações de separação, porventura, propostas com base nestes precedentes, não se permitindo sua rejeição, como verificada na primeira hipótese vertente, de modo a garantir a estabilidade, a coerência e a integridade do sistema jurídico, ora positivadas no art. 926.

\subsection{O RESP 1.247.098-MS}

O recurso especial em comento foi objeto de análise e julgamento pela Quarta Turma do Egrégio Superior Tribunal de Justiça, em março de 2017, o qual estabeleceu precedente de ordem processual, que ora será examinado. Cumpre transcrever a respectiva ementa, em sede propedêutica, in verbis.

RECURSO ESPECIAL. DIREITO CIVIL. FAMÍLIA. EMENDA CONSTITUCIONAL N ${ }^{\circ}$ 66/10. DIVÓRCIO DIRETO. SEPARAÇÃO JUDICIAL. SUBSISTÊNCIA.

1. A separação é modalidade de extinção da sociedade conjugal, pondo fim aos deveres de coabitação e fidelidade, bem como ao regime de bens, podendo, todavia, ser revertida a qualquer momento pelos cônjuges (Código Civil, arts.1571, III e 1.577). O divórcio, por outro lado, é forma de dissolução do vínculo conjugal e extingue o casamento, permitindo que os ex-cônjuges celebrem novo matrimônio (Código Civil, arts. 1571, IV e 1.580). São institutos diversos, com consequências e regramentos jurídicos distintos. 2. A Emenda Constitucional n ${ }^{\circ}$ 66/2010 não revogou os artigos do Código Civil que 
tratam da separação judicial.

3. Recurso especial provido.

(REsp 1247098/MS, Rel. Ministra MARIA ISABEL GALLOTTI, QUARTA TURMA, julgado em 14/03/2017, DJe 16/05/2017)

É imperioso esclarecer que o julgamento não foi unânime, hipótese em que serão investigados os argumentos dos respectivos votos vencedores e o vencido, de lavra do ministro Luiz Felipe Salomão, para melhor abordagem da temática em voga.

\subsection{O VOTO VENCEDOR}

O voto vencedor, proferido pela relatora, ministra Maria Isabel Gallotti, foi acompanhado pelos ministros Antonio Carlos Ferreira, Marco Buzzi e Raul Araújo, e no mérito, após ultrapassada e rejeitada a preliminar suscitada pelo Ministério Público Federal, o qual arguia a competência do Supremo Tribunal Federal para julgamento da matéria por envolver declaração de inconstitucionalidade, enfrentou a permanência ou não da separação judicial (consensual ou litigiosa) ou extrajudicial como instituto existente em nosso ordenamento, ante a supressão de sua menção no atual texto constitucional. ${ }^{22}$

Em linhas propedêuticas, a ministra relatora afirmou sua percepção acerca da diferenciação dos institutos, entendendo pela manutenção e coexistência de ambos, independente da nova redação do dispositivo da Constituição alterado pela EC $66 / 10$.

Afirma que, em análise à literalidade do artigo previsto na Constituição, as alterações ocorridas foram a supressão do requisito temporal e o fim do sistema bifásico, permitindo-se a dissolução do casamento tão somente pelo divórcio, facilitando-o, por constituir verdadeiro direito potestativo dos cônjuges.

Destarte, acresce sua argumentação no sentido de que há uma faculdade dos cônjuges quanto à dissolução do casamento pelo divórcio, ora permitido sem qualquer restrição, não afastando a possibilidade da separação judicial, ainda persistente no Código Civil, considerando que quem pode o mais, pode o menos também.

Ressalta, ainda, que a desconstitucionalização da separação, por si só, não a extingue automaticamente, o que seria uma interpretação equivocada, sendo certo que tal matéria passou a ser objeto de regulação por lei infraconstitucional, tal como

\footnotetext{
$\overline{{ }^{02} \text { Atual redação do } \S 6^{\circ}}$ do art. 206 da Constituição: "O casamento civil pode ser dissolvido pelo divórcio." Redação anterior: "O casamento civil pode ser dissolvido pelo divórcio, após prévia separação judicial por mais de um ano nos casos expressos em lei, ou comprovada separação de fato por mais de dois anos."
} 
ocorreu com a separação de fato, cuja existência não é questionada.

As principais diferenças entre os institutos da separação e do divórcio são destacadas, a saber: a separação, encontra previsão no artigo 1.571, III, do Código Civil e é modalidade de extinção da sociedade conjugal, pondo fim aos deveres de coabitação e fidelidade, bem como ao regime de bens. Trata-se de uma medida temporária e de escolha pessoal dos envolvidos, que podem, a qualquer tempo restabelecer a sociedade conjugal (1.577 CC). O divórcio, por outro lado, é forma de dissolução do vínculo matrimonial, extinguindo-o, de modo a pôr termo ao casamento, consoante expressa redação do $\S 1^{\circ}$ do aludido dispositivo legal. Seus efeitos refletem-se diretamente sobre o estado civil das pessoas envolvidas, permitindo que os ex-cônjuges celebrem novo casamento, o que não ocorre com a separação, salvo se esta for convertida em divórcio (1.580 CC).

Com fulcro nas diferenças apontadas, ressalta a identidade do instituto da separação judicial ou extrajudicial à separação de fato, no tocante às consequências jurídicas, uma vez que ambas põem fim ao regime de bens e aos deveres de coabitação e fidelidade, permitindo, inclusive a formação de nova unidade familiar pelos ex-consortes, pela união estável.

Sustenta não parecer adequada à intervenção do Estado-Juiz na liberdade de escolha dos jurisdicionados que se quiserem valer do processo judicial de separação para fins de produção dos efeitos do rompimento matrimonial, tal como resguardar os direitos da personalidade e patrimoniais, inclusive para futuro entendimento do casal, mesmo após a separação de fato, respaldando-se nos enunciados da V Jornada de Direito Civil ${ }^{03}$, que foram integralmente transcritos. Outro argumento trazido à baila foi o julgamento do Recurso Extraordinário $n^{0} 227.114-S P$, de relatoria do ministro Joaquim Barbosa, pelo Supremo Tribunal Federal, após o advento da aludida emenda constitucional, que tratou do foro competente para o ajuizamento da ação de separação, ratificando sua permanência no ordenamento pátrio, o que restou encampado pelo novo Código de Processo Civil.

Assim, expõe seu entendimento de que não houve a supressão do instituto, mas o requisito temporal, garantindo, assim, a autonomia privada pela efetivação do

\footnotetext{
${ }^{33} 514$ - Art. 1.571: A Emenda Constitucional n. 66/2010 não extinguiu o instituto da separação judicial e extrajudicial. 515 - Art. 1.574, caput: Pela interpretação teleológica da Emenda Constitucional n. 66/2010, não há prazo mínimo de casamento para a separação consensual. 516 - Art. 1.574, parágrafo único: Na separação judicial por mútuo consentimento, o juiz só poderá intervir no limite da preservação do interesse dos incapazes ou de um dos cônjuges, permitida a cindibilidade dos pedidos com a concordância das partes, aplicando-se esse entendimento também ao divórcio. 517 - Art. 1.580: A Emenda Constitucional n. 66/2010 extinguiu os prazos previstos no art. 1.580 do Código Civil, mantido o divórcio por conversão.
} 
princípio da liberdade familiar, diminuindo a interferência estatal na família.

\subsection{O VOTO VENCIDO}

O ministro Luiz Felipe Salomão, redator do voto vencido, destacou que a discussão em comento cinge-se na definição da subsistência (não recepção ou revogação) do instituto da separação judicial no ordenamento jurídico, com a edição da EC 66/2010, o que afasta a exigência de reserva de plenário.

Inicia sua fundamentação ao argumento que o fim da sociedade conjugal e do casamento vem passando por significativas alterações no decorrer da história, que era indissolúvel à luz da concepção canônica da Igreja Católica. Após as reformas legislativas que regulamentaram a separação de corpos, desquite e unicidade do divórcio, chegou-se ao sistema binário, pautado pela discussão da culpa, em que a separação e o divórcio passaram a coexistir, hipótese em que o rompimento passou a ser judicial e, com o advento da lei 11.441/2007, extrajudicial.

Demonstra que a separação judicial põe termo à sociedade conjugal, apesar de manter o vínculo matrimonial, findando os deveres de coabitação e fidelidade recíproca, ao regime de bens (CC, art. 1.576) e possibilitando a retomada do casamento (art. 1577). O divórcio surge a partir da EC 09/77 e da lei $n^{0} 6.515 / 77$ e encerra o vínculo conjugal (CC, art. $1.571, \S 1^{\circ}$ ), independente da prévia partilha de bens (CC, art.1.572), tendo a Constituição estabelecido, originariamente, a possibilidade da dissolução do matrimônio pelo divórcio, após prévia separação judicial por mais de um ano, ou mediante comprovação de separação de fato por mais de dois anos.

Esclarece que nesse passo a EC 66/2010 estabeleceu substancial alteração no dispositivo (art. 226, $\$ 6^{\circ} \mathrm{da} \mathrm{CF} / 88$ ), cuja redação passou a prever a dissolução do casamento pelo divórcio, deixando de estabelecer qualquer prazo para a dissolução do vínculo conjugal. Em razão desta inovação é que se justificou intenso debate doutrinário e jurisprudencial a respeito da subsistência ou não da separação no âmbito do sistema jurídico brasileiro.

A primeira corrente, corroborada pela relatora, defende que remanesce o interesse dos cônjuges na mera separação judicial, haja vista que o casal não daria cabo ao casamento, mas tão somente à sociedade conjugal e, por conseguinte, seria possível o restabelecimento da união rompida, sem necessidade de novo casamento. Ressalta que tal concepção consistiu na orientação adotada nas Jornadas de Direito Civil.

No entanto, demonstra sua discordância, com a devida vênia, filiando-se à 
corrente majoritária lastreada na vontade do próprio poder constituinte derivado, que demonstra entendimento pela abolição do instituto, não sendo mais viável juridicamente a separação de direito.

Em argumento reflexo ao exposto pela relatora, entende tratar-se do reconhecimento da intervenção mínima do Estado na vida privada, como afastamento de intromissões desinfluentes para a dissolução do casamento, primando-se pela nova visão constitucional de reconstrução principiológica das relações privadas. Neste condão, há que se reconhecer o divórcio como medida garantista que concretiza a liberdade humana de se autodeterminar, calcado na afetividade e no direito à vida digna, superando a feição patrimonialista do casamento, em que havia o prestígio do ter em detrimento do ser, bem como o rastro ideológico-religioso de preservação eterna da família. Sustenta, ainda, não haver mais a exigência de uma "fase prévia" de dissolução, com imposição de prazo de "reflexão", com excesso de formalidade e pouca efetividade, mediante manutenção de uma interpretação que privilegia o cônjuge recalcitrante quanto à dissolução que, por meio da separação, pretende apenas punir o outro, com comprometimento da paz social e da administração da Justiça, significando mais gastos financeiros, desgastes emocionais e emperramento do Judiciário, exigindo-se dois processos judiciais para o mesmo fim.

Ressalta que nenhum laço conjugal se mantém em razão de etiquetagem jurídica, mas em razão do amor, afeto, felicidade, desejo dos cônjuges em preservar a família e seu bem-estar, que não é por causa da existência do divórcio ou da separação, ou da exigência de prazos, que se desfazem casamentos. Manifesta sua opinião no sentido de que a mera possibilidade ou eventualidade de reconciliação do casal separado não pode servir de justificativa para mantença do instituto (aliás, o número de casos em que isso acontece é muito pequeno), até porque, em se divorciando, não há impedimento legal para que eles se casem novamente.

Reconhece ser direito potestativo dos cônjuges acabar com a relação por meio do divórcio, independentemente de decurso de prazo ou qualquer outra condição impeditiva ("cláusula de dureza"), devendo a separação de direito ser tida como revogada tacitamente ou não recepcionada pelo texto constitucional.

Finaliza seu voto acrescentando doutrina e jurisprudência do próprio Superior Tribunal de Justiça em outros casos já julgados, que coadunam com sua posição ora exposta, destacando tratar-se de uma norma constitucional de eficácia plena, autoexecutável, de aplicação imediata, notadamente em razão da força normativa da 
Constituição e da incidência dos princípios da máxima efetividade e da interpretação conforme, na lição de Gomes Canotilho, sendo desnecessária a edição de qualquer ato normativo de categoria infraconstitucional para a produção de efeitos.

Sob este ângulo, leciona que o novo CPC, apesar de ter feito previsão em diversos dispositivos do instituto da separação, não pode ser usado como fundamento para julgamento deste caso concreto, por quatro motivos: a) a ação foi proposta sob a vigência do CPC/1973 e o pré-questionamento que ensejou a interposição deste recurso especial foi fundado naquele, hipótese em que vedada a fundamentação pela nova lei, com fulcro na Súmula $211 \mathrm{STJ}$; b) porque a discussão dos autos limita-se ao direito material - instituto da separação - que, deve ser considerado abolido do ordenamento jurídico, sendo certo que o novo CPC não tem o condão de repristiná-lo ou mesmo confirmar sua manutenção no sistema, pois sua função é apenas a de prever o devido procedimento e não criação, modificação ou extinção de direitos materiais; c) porque não compete ao STJ a discussão de inconstitucionalidade incidenter tantum do novo regramento, competindo ao STF tal desiderato. Ademais, o recurso em voga refere-se ao julgamento de questões subjetivas que precisam enfrentar o pedido da demanda, sob pena de nulidade, qual seja, julgamento extra petita; d) porque há entendimento que afasta a arguição de inconstitucionalidade do Código com relação ao tema, uma vez que os dispositivos do novo instrumento se voltariam a regular a situação jurídica dos casais que já se encontravam separados judicialmente (antes da Emenda do Divórcio), haja vista a proteção do ato jurídico perfeito e do direito adquirido (CF, art. $\left.5^{\circ}, \mathrm{XXXVI}\right)$, que deve recair sobre as pessoas que estavam separadas por decisão judicial ou escritura pública, remanescendo o estado civil de separadas. Ou, ainda, por haver posicionamento conferindo interpretação em conformidade com a Constituição (sem redução do texto legal), para reconhecer que a nova lei, ao se valer do termo "separação" sem qualificação, quis tratar da "separação de fato" ou da "separação de corpos", e não da "separação judicial".

Pelo exposto, nega-se provimento ao recurso.

\section{O RESP 1.431.370-SP}

O Egrégio Superior Tribunal de Justiça reiterou o aludido posicionamento acima firmado em recente julgamento pela Terceira Turma, por unanimidade, o que restará examinado. Para tal desiderato, segue a transcrição da respectiva ementa, in 
litteris:

RECURSO ESPECIAL. DIREITO CIVIL. DIREITO DE FAMÍLIA. EMENDA CONSTITUCIONAL N ${ }^{\circ}$ 66/2010. DIVÓRCIO DIRETO. REQUISITO TEMPORAL.

EXTINÇÃO. SEPARAÇÃO JUDICIAL OU EXTRAJUDICIAL. COEXISTÊNCIA.

INSTITUTOS DISTINTOS. PRINCÍPIO DA AUTONOMIA DA VONTADE.

PRESERVAÇÃO. LEGISLAÇÃO INFRACONSTITUCIONAL. OBSERVÂNCIA.

1. A dissolução da sociedade conjugal pela separação não se confunde com a dissolução definitiva do casamento pelo divórcio, pois versam acerca de institutos autônomos e distintos.

2. A Emenda à Constituição $n^{0}$ 66/2010 apenas excluiu os requisitos temporais para facilitar o divórcio.

3. O constituinte derivado reformador não revogou, expressa ou tacitamente, a legislação ordinária que cuida da separação judicial, que remanesce incólume no ordenamento pátrio, conforme previsto pelo Código de Processo Civil de 2015 (arts. 693, 731, 732 e 733 da Lei $\left.\mathrm{n}^{\circ} 13.105 / 2015\right)$.

4. A opção pela separação faculta às partes uma futura reconciliação e permite discussões subjacentes e laterais ao rompimento da relação.

5. A possibilidade de eventual arrependimento durante o período de separação preserva, indubitavelmente, a autonomia da vontade das partes, princípio basilar do direito privado.

6. O atual sistema brasileiro se amolda ao sistema dualista opcional que não condiciona o divórcio à prévia separação judicial ou de fato. 7. Recurso especial não provido.

(REsp 1431370/SP, Rel. Ministro RICARDO VILLAS BÔAS CUEVA, TERCEIRA TURMA, julgado em 15/08/2017, DJe 22/08/2017)

Nesta oportunidade, consoante já restou ressaltado, o recurso foi decidido por unanimidade pelos votos dos Excelentíssimos ministros Ricardo Villas Bôas Cueva, relator, Marco Aurélio Belizze, Moura Ribeiro, Nancy Andrighi e Paulo de Tarso Sanseverino.

A hipótese vertente versava sobre a possibilidade de prosseguimento de ação de separação judicial litigiosa, em que uma das partes a refutava, entendendo cabível apenas o divórcio direto, por força da redação da EC 66/2010.

A magistrada a quo interpelou as partes acerca da possibilidade de conversão do rito de separação para o divórcio, o que foi rejeitado por uma delas, tendo a demanda prosseguida na forma do pedido inicial. Inconformada, a outra interpôs o recurso de agravo de instrumento que foi negado provimento pela Corte de Justiça, 
mantendo a decisão de primeiro grau. Com fundamento em divergência jurisprudencial e preclusão da matéria impugnada, a parte vencida interpôs o Recurso Especial em apreço, cujo voto ora segue em análise.

Antes, porém, compete mencionar que em sua promoção, o Ministério Público Federal opinou pelo não provimento do recurso sob o argumento de que haveria, pelo menos, três teorias a respeito das consequências da EC 66/2010, a saber: a) inexistência da separação judicial, apenas o divórcio sem prazo para sua realização; b) separação e divórcio são coexistentes, porém independentes, sem que aquela seja pressuposto deste ou qualquer prazo de separação de fato; e c) inexistência de qualquer requisito imposto pela Constituição, competindo a regulação da matéria à lei infraconstitucional.

$O$ voto do relator restou iniciado com destaque para a controvérsia, que se cingia na ab-rogação ou não do instituto da separação judicial após o advento da EC 66/2010. Inicialmente afastou o cabimento do recurso para análise da discussão acerca da preclusão diante da falta pré-questionamento, passando ao julgamento da divergência jurisprudencial.

Neste diapasão, registram-se as diferenças entre a separação e o divórcio e os respectivos efeitos, o que já restou sobejamente demonstrado nos votos do outro precedente acima verificado. Conclui o posicionamento registrando que a alteração constitucional não revogou, expressa ou tacitamente, a legislação ordinária que regula o procedimento da separação, consoante exegese do art. $2^{\circ}$, $\S \S 1^{\circ}$ e $2^{\circ}$, da Lei de Introdução às Normas do Direito Brasileiro (decreto-lei no 4.657/1942). Por esta razão, a redação da emenda apenas facultou às partes dissolver direta e definitivamente o casamento civil, por meio do divórcio, objeto de nova disciplina, tendo em vista a supressão do requisito temporal até então existente.

Ratifica que a supressão de requisitos para o divórcio não afasta a existência de um procedimento judicial ou extrajudicial de separação conjugal, que passou a ser opcional a partir da sua promulgação. Menciona que a Corte Especial já havia decidido em igual sentido em duas outras oportunidades, quais sejam, nos julgamentos do SEC $\mathrm{n}^{\mathrm{O}} 5.302 / \mathrm{EX}$, de relatoria da ministra Nancy Andrighi, julgado em 12/05/2011 e no SEC no 4.445/EX, de relatoria do ministro Raul Araújo, julgado em $05 / 05 / 2015$.

Destarte, registra que a possibilidade de discussões laterais e subjacentes ao rompimento das partes em um procedimento autônomo de separação, remanesce 
incólume no ordenamento pátrio. A permissão de eventual arrependimento durante o período de separação preserva a autonomia da vontade das partes, porquanto poderão os cônjuges o restabelecimento do casamento sem a necessidade de contrair novas núpcias, bastando a informação ao juízo, consoante o disposto no artigo 1.577 CC/2002.

Aduz, ainda, que quem pode o mais (divórcio), pode o menos (separação), destacando que a emenda apenas facilitou a obtenção do divórcio sem causar mudanças excludentes nos demais institutos do direito de família, consubstanciando sua assertiva no voto vencedor do precedente suso analisado - REsp n ${ }^{0}$ 1.247.098MS.

Por fim, registram-se que, independente das razões, as partes poderão valer-se da separação para obtenção dos efeitos pretendidos, seja pela via judicial ou extrajudicial, inclusive com a previsão no Código de Processo Civil vigente.

Destaca, ainda, que em análise de direito comparado percebe-se que o Brasil adotou o sistema denominado "dual opcional", em que se faculta a escolha do divórcio ou separação pelas partes, tal qual, em Portugal, França e Itália. Em sede doutrinária, menciona a tese de Washington de Barros Monteiro e Regina Beatriz Tavares $^{04}$, concluindo que não se poderia considerar revogado o instituto da separação

04 "[...] Sobre a manutenção da separação em nosso ordenamento jurídico, retoma-se o teor da ementa da EC n. 66/2010, segundo a qual somente foram suprimidos os requisitos temporais de um ano de separação judicial ou de dois anos de separação de fato. Não ocorreu a supressão do instituto da separação. Se pudesse ter ocorrido a eliminação da separação, chegar-se-ia à absurda conclusão que também a separação de fato estaria excluída de nosso sistema jurídico. Além de a separação possibilitar o restabelecimento da sociedade conjugal por meio de mera petição juntada aos autos do respectivo processo (Cód. Civil, art. 1.577), de modo que os cônjuges podem preferir essa forma dissolutória, em vez de romperem definitivamente o vínculo conjugal por meio do divórcio, a manutenção da separação é necessária em respeito ao direito fundamental da liberdade, previsto no art. $5^{\circ}$, VIII, como se verá a seguir. Como direito fundamental à liberdade, consta do inciso VIII do art. $5^{\circ}$ que 'ninguém será privado de direitos por motivo de crença religiosa ou de convicção filosófica ou política'. A eliminação da separação judicial importaria em violação a esse direito fundamental, já que há religiosos que não admitem o divórcio e somente podem regularizar seu estado civil pela separação que não dissolve o vínculo conjugal. Isso ocorre com os Evangélicos e também com os Católicos Ortodoxos Romanos, que ficariam privados do direito à regularização de seu estado civil. No que se refere aos Católicos, o Direito Canônico admite a separação com permanência do vínculo conjugal, mas não admite o divórcio. Vide Código Canônico, Título VII - Do matrimônio, Capítulo IX - Da separação dos cônjuges, art. $2^{\circ}$ - Separação com permanência do vínculo. Assim, eliminar a separação judicial equivaleria a retirar dos que professam a religião Católica Ortodoxa Romana o direito de regularizarem seu estado civil por meio da separação judicial, obrigando-os a permanecer como separados de fato. Se suprimido o instituto da separação, uma de duas hipóteses obrigatoriamente ocorreria. Numa, o cônjuge que professa religião que não admite o divórcio se divorciaria e ficaria irregular perante sua crença, privado, assim, do livre exercício religioso. Noutra, o cônjuge que professa essa religião manter-se-ia sempre em separação meramente de fato e estaria irregular perante o Estado, vivendo em situação híbrida, que nunca é recomendável. Em suma, se viesse a ser eliminada a separação, seriam desrespeitados os direitos fundamentais à regularização do estado civil em razão de crença. Portanto, a manutenção da espécie dissolutória culposa e da separação em nosso ordenamento jurídico não está atrelada a mero debate entre divorcistas e antidivorcistas, ou entre católicos e não católicos, mas, sim, à preservação dos direitos fundamentais. Exatamente por ser o Brasil um Estado laico, deve-se assegurar aos religiosos o exercício de seus direitos fundamentais. [...]". (Washington de Barros Monteiro e Regina Beatriz Tavares, Curso de Direito Civil, Direito de Família, no 2, 43. ed, 2016, São Paulo: Saraiva, p. 349-350 - grifou-se). 
judicial, salvo se uma nova normatização assim regulamentar.

Consubstanciado nas razões expostas, negou-se provimento ao recurso.

\section{DIVÓRCIO X SEPARAÇÃO}

Antes de adentrar na análise da temática em voga, acerca da diferença entre divórcio e separação, que conduziu a tônica dos votos acima expostos, é relevante ressaltar que, acima de tudo, a família não é só um direito constitucionalmente reconhecido no ordenamento pátrio, mas uma verdadeira garantia institucional, que segundo Paulo Bonavides ${ }^{05}$, vai existir independente de ter ou não posições contramajoritárias.

Por esta razão, as discussões trazidas a lume estreitam-se na análise da viabilidade procedimental para o rompimento dos efeitos jurídicos decorrentes do fim do casamento, sem abalar as insígnias estruturais da concepção de família.

Neste jaez, cumpre destacar as principais características dos institutos em voga, de forma bem sintética, considerando que já restou demasiadamente esgotada a problemática nos fundamentos dos votos outrora expostos.

Guilherme Couto de Castro destaca que a separação judicial pode ser considerada uma forma voluntária de terminação da sociedade conjugal, por iniciativa de um ou ambos os cônjuges, pondo fim à sociedade conjugal. E, esclarece, seu vínculo matrimonial subsiste, embora fraquejado. Já o divórcio extingue a sociedade conjugal e o vínculo matrimonial. ${ }^{06}$

Rodrigo da Cunha Pereira ${ }^{07}$ expõe com maestria a principal distinção entre eles:

\footnotetext{
${ }^{05}$ A família é uma garantia institucional, que visa a assegurar uma proteção constitucional, denominada de qualificada, na linguagem de Carl Schmitt, com uma pauta mínima de intangibilidade. A eficácia de tal garantia deve se dar de modo absoluto, aplicando-a toda a força da proteção constitucional contra sua total supressão ou, ainda, contra uma lesão ao seu mínimo essencial. BONAVIDES, Paulo. Curso de direito constitucional. 12.ed. São Paulo: Malheiros, 2002, p. 495.

${ }^{06}$ E destaca que em relação aos efeitos: "o separado não pode se casar novamente, nem mesmo com cônjuge de quem se separou; se os separados quiserem refazer a sociedade conjugal, haverá mera reconciliação, e não novo casamento (art. 1.577 do CC). [...] Os efeitos oriundos da sociedade conjugal - como a fidelidade, coabitação e regime de bens - cessam com a separação judicial. A longa separação de fato, cabal e inequívoca, também é apta a produzir a cessação de tais deveres. [...] Os efeitos da separação, retroagem à data da separação de corpos (art. $8^{\circ}$ da Lei n ${ }^{\circ}$ 6.515/77). Se, após este marco, houver a aquisição de bens, eles não se comunicam, mesmo que o regime seja o da comunhão universal. Como se disse, a cessação do regime de bens retroage à data da decisão liminar que autorizou a separação de corpos.”. CASTRO, Guilherme Couto. Direito Civil lições. Niterói: Impetus, 2007, p. 280-281.

${ }^{07}$ PEREIRA, Rodrigo da Cunha. Divórcio. Teoria e Prática. 4.ed. São Paulo: Saraiva, 2013, p. 47.
} 
Desde a Lei n. 6.515/1977 tem sido feita a distinção entre "terminar" e "dissolver" o casamento. Foi necessário este "jogo" de palavras para dar alguma coerência ao incoerente e inútil instituto da separação judicial. Como já dito, ele veio substituir o desquite para satisfazer àqueles cuja religião não permite o divórcio. Dissolver ou terminar um casamento tem o mesmo sentido: o casamento acabou. A diferença essencial é que não se pode casar quem apenas se separou judicialmente, enquanto com o divórcio é possível casar novamente.

No entanto, é imperioso notar que a diferença não se limita a esta, qual seja, a possibilidade de rompimento do vínculo para fins de permissão de novas núpcias. Outras podem ser destacadas, senão vejamos: o estado civil do cônjuge separado em caso de morte do outro é de viúvo, pois não houve o rompimento do vínculo; pela mesma razão, os cônjuges separados que pretenderem restabelecer o casamento, deverão fazê-lo por meio de simples petição ao juiz, na forma do art. $1.577 \mathrm{CC}$, ao passo que os divorciados deverão promover novo processo de habilitação e submeterem-se às formalidades legais de novo casamento; é possível perceber, ainda, os efeitos da partilha de bens, entendendo ser este o fator mais complicador. Isto porque, o artigo 1.575 CC impõe como condição para a separação judicial que os cônjuges também estejam separados de corpos, além da prévia partilha de bens, enquanto que para o divórcio, o artigo 1.581, ratificado pela Súmula 197 STJ, permite a realização do divórcio sem a respectiva partilha; dentre outros.

No que tange a esta peculiaridade, antes mesmo da EC 66/2010, o Superior Tribunal de Justiça já havia enfrentado a questão para destacar que a prévia partilha de bens não poderia ser empecilho para a dissolução da sociedade conjugal, por se tratar de direitos existenciais que mereceriam suporte jurídico distinto dos patrimoniais. ${ }^{08}$

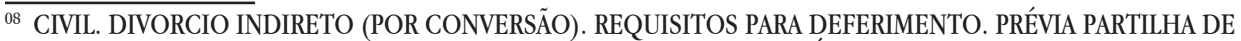
BENS. INEXIGIBILIDADE. NOVA PERSPECTIVA DO DIREITO DE FAMÍLIA. ARTS. 1.580 E 1.581 DO CC/02. 1. A regulamentação das ações de estado, na perspectiva contemporânea do fenômeno familiar, afasta-se da tutela do direito essencialmente patrimonial, ganhando autonomia e devendo ser interpretada com vistas à realização ampla da dignidade da pessoa humana. 2 . A tutela jurídica do direito patrimonial, por sua vez, deve ser atendida por meio de vias próprias e independentes, desobstruindo o caminho para a realização do direito fundamental de busca da felicidade. 3. O divórcio, em qualquer modalidade, na forma como regulamentada pelo $\mathrm{CC} / 02$, está sujeito ao requisito único do transcurso do tempo. 4. Recurso especial conhecido e não provido. (REsp 1281236/SP, Rel. Ministra NANCY ANDRIGHI, TERCEIRA TURMA, julgado em 19/03/2013, DJe 26/03/2013) 


\section{DAS ESPÉCIES DE SEPARAÇÃO NO DIREITO BRASILEIRO}

O instituto da separação judicial, que possuía status constitucional antes da EC 66/2010, o que já restou sobejamente demonstrado nos votos dos ministros acima expostos, encontra-se devidamente regulamentado no Código Civil vigente, determinando sua eficácia para pôr termo à sociedade conjugal (art. 1.571, III), importando para a separação de corpos e partilha de bens (art. 1.575) e, ainda, para pôr fim aos deveres de coabitação e fidelidade recíproca e ao regime de bens (art. $1.576)$.

Ocorre, porém, que o instituto da separação coexiste no ordenamento com outras modalidades, que ora merecem ser enfrentadas e esclarecidas, em especial no que tange às respectivas finalidades, para melhor compreensão do tema.

\subsection{SEPARAÇÃO JUDICIAL}

A separação judicial, como já exposta em diversas passagens alhures, é aquela que "termina" o vínculo conjugal, sem "dissolvê-lo", utilizando-se das expressões empregadas por Rodrigo da Cunha Pereira" ${ }^{09}$.

É importante esclarecer que nesta concepção emprega-se a expressão separação judicial como sendo a litigiosa, uma vez que no próximo item será analisada sua vertente consensual.

De fato, a principal fundamentação para a preservação do instituto da separação judicial, até o advento da EC 66/2010 era a análise da culpa pelo rompimento do casamento, cujos efeitos eram expressos na lei. ${ }^{10}$

O Código Civil em seu artigo 1.572 estabelece as causas que justificariam o pedido de separação judicial, permitindo a imputação de culpa ao outro por qualquer ato que implicasse em grave violação dos deveres do casamento e tornasse insuportável a vida em comum. E, ainda, no artigo 1.578 expõe que o cônjuge culpado pela separação perderia o direito de usar o sobrenome do outro.

\footnotetext{
${ }^{09}$ PEREIRA, Rodrigo da Cunha. Divórcio. Teoria e Prática. 4.ed. São Paulo: Saraiva, 2013, p. 47.

10 "Mas embora o fato tempo deponha em desfavor da separação judicial e sua conversão, é certo que, em face do novo sistema legal, a separação judicial oferece a vantagem de nela ser possível, em tese, discutir a causa da separação, a permitir daí extraírem-se certas consequências jurídicas a benefício do cônjuge inocente." CAHALI, Yussef Said. Divórcio e Separação. 11.ed. São Paulo: Revista dos Tribunais, 2005, p. 70.
} 
A mesma tônica já era determinada pela lei do divórcio $\left(n^{0} 6.515 / 77\right)^{11}$, que ainda estabelecia outras sanções para o cônjuge culpado, são elas: guarda de filhos menores $^{12}$; ao uso do sobrenome ${ }^{13}$; e a fixação de alimentos ${ }^{14}$, o que justifica a grande importância de uma adequada interpretação à aludida Emenda Constitucional, pela gama de efeitos que a separação judicial implica(va).

Com o advento do atual Código Civil, doutrina e jurisprudência passaram a admitir a revogação tácita dos direitos materiais regulamentados na lei do divórcio, mantendo-se seus efeitos processuais, o que justifica toda esta discussão.

No entanto, é forçoso concluir que após a EC 66/2010, não só os prazos para ajuizamento das competentes ações de separação ou divórcio foram extintos, o que já foi enfrentado nos votos dos acórdãos em voga, como também a demonstração de culpa para justificar a causa de pedir e o consequente recebimento das demandas com pedido de separação, aspectos estes processuais.

Por esta razão, há uma tendência majoritária a se interpretar o Código Civil e a lei do divórcio ( $\mathrm{n}^{\mathrm{0}}$ 6.515/77), sob a vertente da existência de uma única causa apta à separação do casal, a ruptura da vida em comum - para a corrente que sustenta sua manutenção-, sem qualquer discussão da culpa a ser apurada pelo fim do casamento. Esta doutrina sustenta que esta seria a causa da separação, a ser pretendida em juízo independentemente de prazo, justificado pela regra do artigo 1.572, $\S 1^{\circ}$ CC (separação de fato superior a 01 ano e reconstituição impossível), afastando de forma pragmática os efeitos suso mencionados. ${ }^{15}$

Para Regina Beatriz Tavares da Silva, ${ }^{16}$ ainda sobrevivem alguns resquícios dos efeitos da culpa na separação judicial, como a possibilidade de fixação de alimentos e, quiçá, uma reparação civil, por danos materiais ou morais decorrentes deste fato, causador do fim do casamento.

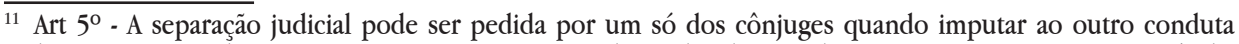
desonrosa ou qualquer ato que importe em grave violação dos deveres do casamento e tornem insuportável a vida em comum.

${ }^{12}$ Art 10 - Na separação judicial fundada no "caput" do art. $5^{\circ}$, os filhos menores ficarão com o cônjuge que a e não houver dado causa.

${ }^{13}$ Art 17 - Vencida na ação de separação judicial (art. $5^{\circ}$ "caput"), voltará a mulher a usar o nome de solteira. § $1^{\circ}$ Aplica-se, ainda, o disposto neste artigo, quando é da mulher a iniciativa da separação judicial com fundamento nos $\S \S 1^{\circ}$ e $2^{\circ}$ do art. $5^{\circ}$. $\S 2^{\circ}$ - Nos demais casos, caberá à mulher a opção pela conservação do nome de casada. Art 18 - Vencedora na ação de separação judicial (art. $5^{\circ}$ "caput"), poderá a mulher renunciar, a qualquer momento, o direito de usar o nome do marido.

${ }^{14}$ Art 19 - O cônjuge responsável pela separação judicial prestará ao outro, se dela necessitar, a pensão que o juiz fixar.

15 SILVA, Regina Beatriz Tavares da. A Culpa nas relações de família. In: DELGADO, Mário Luiz; ALVES, Jones Figueiredo (Org.). Questões Controvertidas no Direito de Família e das Sucessões. São Paulo: Método, 2005, p. $67-103$.

${ }^{16}$ Idem.
} 
A manutenção da chama acesa para não justificar o sepultamento definitivo da separação judicial no Brasil consiste, exatamente, nos argumentos trazidos à baila nos votos vencedores, com fulcro na opção procedimental de quaisquer dos cônjuges, consubstanciado na liberdade de escolha, se pela via do divórcio direto ou pela via da separação, inicialmente, podendo ser convertida em divórcio futuramente ${ }^{17}$ ou, pelo simples restabelecimento do vínculo, caso resolvam "tentar novamente", sem a necessidade de novo casamento. Em síntese, a validade da separação como um verdadeiro "prazo de reflexão" para as partes.

\subsection{SEPARAÇÃO CONSENSUAL}

A separação consensual é aquela que produz os mesmos efeitos da separação judicial litigiosa, acima analisada, sendo certo que é emanada do mútuo consentimento dos cônjuges que, por intermédio de demanda judicial de jurisdição voluntária, submetem conjuntamente o mesmo pedido de terminação do vínculo conjugal.

Assim, tudo o que restou enfrentado em sede de separação litigiosa, vale para a hipótese vertente, exceto o procedimento a ser adotado.

$\mathrm{O}$ novo $\mathrm{CPC}$ regulou os procedimentos de jurisdição voluntária relativos às ações de divórcio, separação consensual, extinção de união estável consensual e alteração de regime de bens do casamento nos artigos 731 a 734 .

Considerando a expressa menção à possibilidade de se formular um pedido conjunto endereçado ao juiz para homologar o interesse dos cônjuges na separação consensual, é que se justificou a retomada da discussão em voga acerca da manutenção ou não do instituto no ordenamento pátrio.

Não se pode olvidar que a versão consensual da separação pode ser judicial (arts. 731 a 734 do CPC) ou extrajudicial, desde que, neste caso, preencha os requisitos da lei $\mathrm{n}^{0} 11.441 / 2007^{18} \mathrm{e}$, atualmente, do art. 733 do CPC.

\footnotetext{
$\overline{17}$ Enunciado 517 da V Jornada de Direito Civil - Art. 1.580: A Emenda Constitucional n. 66/2010 extinguiu os prazos previstos no art. 1.580 do Código Civil, mantido o divórcio por conversão.

${ }^{18}$ Art. $3^{\circ}$. A separação consensual e o divórcio consensual, não havendo filhos menores ou incapazes do casal e observados os requisitos legais quanto aos prazos, poderão ser realizados por escritura pública, da qual constarão as disposições relativas à descrição e à partilha dos bens comuns e à pensão alimentícia e, ainda, ao acordo quanto à retomada pelo cônjuge de seu nome de solteiro ou à manutenção do nome adotado quando se deu o casamento.
} 


\subsection{SEPARAÇÃO DE FATO}

A separação de fato, como o próprio termo a sugere, é aquela que configura o fim do relacionamento e da comunhão de vida em comum, justificando a conclusão da essência do matrimônio.

Para Pena Jr, caracteriza-se pelo fim do vínculo afetivo entre os cônjuges e a consequente ruptura da comunhão plena de vida, sem o propósito da reconstituição. Destaca que ocorre sem a interferência estatal, mas produz importantes efeitos, assim como na separação judicial. ${ }^{19}$

Cumpre destacar que separação de fato não se confunde com separação de corpos, em que pese produzirem o mesmo efeito, qual seja, a extinção da vida em comum e, consequentemente, os deveres do casamento. ${ }^{20}$

A separação de corpos é a separação cautelar, determinada por ordem judicial, o que será melhor analisada no item adiante.

Para Maria Berenice Dias ${ }^{21}$, a separação de fato e/ou a separação de corpos seriam instrumentos jurídicos válidos e suficientes para garantir os efeitos pretendidos com a tese de manutenção da separação, qual seja, estabelecer um "prazo de reflexão" para o casal, podendo, inclusive, ser consensual (judicial ou por escritura pública). Nestas hipóteses, restariam suspensos os deveres do casamento e cessada a comunicabilidade dos bens. ${ }^{22}$

Ressalta que em caso de reconciliação, tudo voltaria a ser como antes, sem a necessidade de revogação da separação de corpos, resguardada, apenas, a partilha patrimonial, em que se configurariam incomunicáveis, bens e dívidas contraídas por cada um dos cônjuges individualmente neste período.

\footnotetext{
${ }^{19}$ A separação de fato produz a maior parte dos efeitos da separação judicial, senão vejamos: 1) permite, por exemplo, a modificação não só da guarda dos filhos como do poder familiar; 2) autoriza o afastamento da presunção de paternidade decorrente do casamento, até porque, "se eles estão separados de fato, não há como sustentar a base de probabilidade de que o marido seja pai do filho da mulher com a qual está formalmente casado; 3) o dever de assistência se transforma em obrigação alimentar; 4) cessa o dever de coabitação e fidelidade, podendo inclusive, os separados de fato, constituir união estável. Só não podem casar. PENA JR., Moacir César. Direito das pessoas e das famílias: doutrina e jurisprudência. São Paulo: Saraiva, 2008, p. 226.

${ }^{20}$ A aludida diferença foi enfrentada no voto vencido do Ministro Luiz Felipe Salomão, p. 34 e ora segue transcrita: "Ressalte-se que a separação de fato e a separação de corpus estão mantidas no sistema, até porque a primeira "somente ocorre no plano físico e extrajudicial, não se confundindo com a separação de direito ou jurídica, pois não gera os mesmos efeitos concretos. Na verdade, a separação de fato constitui uma separação informal, caracterizada pelo distanciamento corporal ou afetivo dos cônjuges". Com efeito, "a separação de fato está valorizada diante da EC 66/2010, pois em muitos casos pode assumir o papel da antiga separação de direito" (TARTUCE, Flávio. Ob. cit., p. 228). Já a segunda remanesce como medida de proteção preventiva da dignidade, "devendo ser adotada para evitar futuro atentado contra a personalidade de um dos consortes, pouco interessando se já há sinais externos de violência. É uma salvaguarda à ampla proteção da personalidade (não só a física, mas também psíquica) dos esposos" (FARIAS, Cristiano Chaves. Op.cit., p. 397)."

${ }^{21}$ DIAS, Maria Berenice. Manual de Direito das Famílias. 9.ed. São Paulo: Revista dos Tribunais, 2013, p.308.

${ }^{22}$ Tese ratificada por precedentes do STJ: REsp 86.302-RS e REsp 555.771/SP.
} 


\subsection{SEPARAÇÃO CAUTELAR}

A separação cautelar era prevista no CPC/1973 dentre "as outras medidas provisionais", no art. 888, VI, então denominada "afastamento temporários de um dos cônjuges da morada do casal". ${ }^{23}$

Com o advento do novo CPC, é possível afirmar que restou mantida a possibilidade de sua formulação em juízo, com uma nova roupagem, denominada de tutela de urgência, com espeque nos artigos 301 c/c 305 a 310, o que será enfrentado a posteriori.

Esta medida de natureza precária tem por objetivo garantir a integridade física e/ou psicofísica dos cônjuges e filhos, em caso da insuportabilidade da vida em comum do casal, com o afastamento de um deles do lar conjugal. A princípio, os efeitos da medida devem-se perdurar enquanto pendente a demanda principal de divórcio ou separação, podendo ser revogada a qualquer momento, se outras circunstâncias advindas no curso do feito puderem justificá-la.

Para Cahali ${ }^{24}$ não é necessária para seu deferimento a exposição da causa de pedir da ação de separação ou divórcio, e sequer a comprovação da insuportabilidade da vida em comum. Bastaria a demonstração por meio de uma instrução sumária, da existência de um conflito grave entre o casal, hipótese em que seria pertinente a devida separação de corpos.

A própria lei do divórcio prevê a possibilidade de se determinar a separação de corpos por meio de medida cautelar. ${ }^{25}$

Por fim, cumpre mencionar que há corrente permitindo a realização de separação de corpos de forma consensual, pela via administrativa, quando ausentes menores e incapazes e presentes os demais requisitos legais, considerando a inexistência da vedação na lei no $11.441 / 2007 .{ }^{26}$

\footnotetext{
${ }^{23}$ Para Ovídio A. Baptista da Silva o que se busca efetivamente com a medida é o estado de separação jurídica dos cônjuges, que nada tem a ver com sua provável mas não necessária separação física que a ideia de afastamento da morada do casal poderia sugerir. Em verdade, a provisional de separação de corpos não importa necessariamente afastamento de um dos cônjuges do domicílio conjugal. SILVA, Ovídio A. Baptista da. Do Processo Cautelar. 3.ed. Rio de Janeiro: Forense, 2001, p.590.

${ }^{24}$ CAHALI, Yussef Said. Divórcio e Separação. 11.ed. São Paulo: Revista dos Tribunais, 2005, p. 436.

${ }^{25}$ Lei $\mathrm{n}^{\mathrm{o}} 6.515 / 77$ - art. $7^{\circ}, \S 1^{\circ}$ - A separação de corpos poderá ser determinada como medida cautelar.

${ }^{26}$ Cf. MADALENO, Rolf. Curso de Direito de Família. 4.ed. Rio de Janeiro: Forense, 2011, p. 217.
} 


\section{EFEITOS PROCESSUAIS DA SEPARAÇÃO APÓS EC/66 E NOVO CÓDIGO DE PROCESSO CIVIL}

\subsection{AÇÕES DE FAMÍLIA}

O Código de Processo Civil Brasileiro - lei $n^{0} 13.105 / 2015$, em ação inovadora, reservou um capítulo destinado ao regulamento das demandas de família, nos artigos 693 a 699, objetivando estabelecer medidas específicas que devem ser utilizadas nos processos em curso nas varas de família, como o emprego de esforços para uma solução consensual do conflito, seja mediante a submissão imediata destas a audiências de mediação e conciliação, seja pela possibilidade de suspensão do processo; dentre outras.

Entretanto, convém salientar que as regras suso mencionadas, estão inseridas no capítulo que regula os procedimentos especiais de jurisdição contenciosa, consoante expressa disposição do art. 693, a saber: "As normas deste Capítulo aplicam-se aos processos contenciosos de divórcio, separação, reconhecimento e extinção de união estável, guarda, visitação e filiação.", sendo certo que os procedimentos que não envolvem lide foram regulados em capítulo próprio, nos artigos 731 a 734 , o que já restou esclarecido.

O que é interessante notar é que nas duas hipóteses ventiladas, a lei processual menciona a manutenção da separação como instituto jurídico existente no ordenamento vigente, o que fomenta a discussão em voga.

Considerável parte da doutrina brasileira já havia demonstrado razões suficientes para extirpar a separação como instrumento processual apto à terminação do casamento, após a EC 66/2010, o que inclusive foi o fundamento do voto vencido do primeiro precedente analisado. No entanto, com o advento do novo CPC, a discussão foi trazida à tona, em razão da sua expressa manutenção, servindo, inclusive, como um dos argumentos - obter dictum, utilizados nos votos vencedores, vindo a firmar a jurisprudência da Corte.

Esta é a razão para que sejam tecidas algumas considerações importantes à luz de uma interpretação adequada da nova legislação processual, de modo que se torne viável a recepção destas demandas junto ao órgão judicante, evitando prejuízos de custo e tempo às partes envolvidas, ora destinatárias de uma prestação jurisdicional eficaz. 
Neste jaez, e em especial com base nestes precedentes ora ventilados, é conveniente considerar que o ajuizamento de uma ação de separação judicial, seja ela consensual ou litigiosa, implicará no dever do magistrado em recebê-la, após verificação das regras processuais pertinentes.

Não seria razoável admitir a recusa tão somente pelo fato de se tratar de ação de separação, como a que motivou a formação do primeiro precedente $s u b$ examine, o que demandaria custo e ineficiência da prestação jurisdicional, incompatível com as regras processuais vigentes e o próprio Estado democrático de Direito.

Assim sendo, compete analisar as possíveis etapas que o magistrado poderia/deveria determinar para a devida condução do feito, após o recebimento da petição inicial, senão vejamos.

A primeira delas que se reputa uma das mais importantes etapas do procedimento de acordo com a nova lei processual, seria a designação de uma audiência preambular, na forma do art. 694 do CPC, devendo ser presidida pelo juiz togado que, na qualidade de gestor do processo, teria a possibilidade de alcançar o real interesse das partes, podendo incentivar o acordo, ou encaminhar as partes para submissão ao processo de mediação e/ou conciliação conforme o caso, para uma possível autocomposição, quiçá, com suspensão do processo.

Nesta primeira audiência com as partes, frise-se, a ser realizada pelo magistrado, representaria o primeiro ato processual após o recebimento da petição inicial, garantindo a celeridade e a efetividade necessárias aos feitos de família, mormente aos conflitos existenciais. Nesta ocasião, poderá ser auxiliado por expert do juízo de modo que possa colher, ainda que de forma incipiente, o depoimento das partes e/ ou filhos, seja no ato ou mediante determinação de estudo psicossocial, se aplicável ao caso, que servirá de supedâneo para as indispensáveis decisões a serem tomadas nesta fase. ${ }^{27}$

Em caso de percepção de alto grau de litigiosidade, o julgador disporia de outras medidas processuais previstas em lei para determinar o prosseguimento do feito na forma do artigo 697 do CPC, que ora serão verificadas.

\subsection{FLEXIBILIZAÇÃO PROCEDIMENTAL}

É irrefragável que o ajuizamento de demandas de separação pode servir como um subterfúgio para deflagrar a lide ou iniciar uma tentativa de solução con-

\footnotetext{
${ }^{27}$ Cf. MEDINA, Valéria Julião Silva. Processo de Família e o novo CPC. Curitiba: Juruá, 2017, p. 150-153.
} 
sensual que não foi obtida extrajudicialmente entre as partes, em especial porque os conflitos de família envolvem demanda reprimidas, sentimentos que podem obstaculizar uma solução ideal.

Diante desta inaptidão para resolução dos próprios problemas, as partes submetem ao Poder Jurisdicional tal desiderato, hipótese em que o juiz dispõe de uma ferramenta processual perfeita para conduzir o processo de acordo com as peculiaridades da causa, qual seja, a flexibilização procedimental, de acordo com o disposto no artigo $139, \mathrm{VI}^{28}$ do novo CPC.

Não é demasiado registrar que a aludida flexibilização encontra espeque, ainda, no princípio da eficiência, sufragado pelo artigo $8^{\circ}$ da lei processual ${ }^{29}$, que garante uma "permissão" ao magistrado para aplicar o melhor direito ao caso concreto. $^{30}$

Esta é a razão para se sustentar pela necessidade de o juiz designar uma audiência inaugural, presidindo-a, tão logo receba a petição inicial da ação de separação judicial, de modo que possa obter contato direto com as partes, indagando-as acerca da real intenção da demanda, se apenas para justificar os efeitos patrimoniais ou, de fato, obter um "prazo de reflexão", hipótese em que poderá, no primeiro caso, convertê-la em divórcio e fazer a partilha de bens, e no segundo, recebê-la como uma separação cautelar, e/ou como uma tutela antecipada que possa se tornar estabilizada, competindo às partes requerer a qualquer momento sua conversão em divórcio.

E não é só. Na aludida audiência, o juiz poderia avaliar as circunstâncias da causa e, inclusive, colher provas para análise de eventual pedido de tutela de urgência, qualificando-a como uma justificação, de modo a permitir uma análise mais apropriada da lide e a devida fundamentação a estes pedidos.

Neste diapasão, cumpre demonstrar as novas regras acerca das tutelas provisórias trazidas pelo novo CPC.

${ }^{28}$ Art. 139. O juiz dirigirá o processo conforme as disposições deste Código, incumbindo-lhe: [...] VI - dilatar os prazos processuais e alterar a ordem de produção dos meios de prova, adequando-os às necessidades do conflito de modo a conferir maior efetividade à tutela do direito;

${ }^{29}$ Art. 8o. Ao aplicar o ordenamento jurídico, o juiz atenderá aos fins sociais e às exigências do bem comum, resguardando e promovendo a dignidade da pessoa humana e observando a proporcionalidade, a razoabilidade, a legalidade, a publicidade e a eficiência.

${ }^{30}$ A eficiência é uma noção relacionada com o desempenho de entes privados consistindo num vínculo entre custo e resultado, ou na relação entre finalidades lucrativas e utilização dos recursos disponíveis. Em outras palavras, a eficiência na atividade econômica está presente se houver, a um só tempo, aumento dos ganhos e diminuição dos custos. [...] O Princípio da eficiência está relacionado com a gestão do processo e com o princípio da adequação. $\mathrm{O}$ juiz, para livrar-se da rigidez procedimental e para ajustar o processo às peculiaridades do caso deve adaptar o procedimento, mas deve fazê-lo de modo eficiente. CUNHA, Leonardo Carneiro da. A previsão do princípio da eficiência no projeto do novo Código de Processo Civil brasileiro. 2014. Disponível em: www.academia.edu. Acesso 10 abr 2017. 


\subsection{TUTELAS PROVISÓRIAS}

Em grande parte das demandas de família, em razão da peculiaridade dos direitos envolvidos, há pedido de tutela de urgência, seja de natureza cautelar, seja antecipada, o que empreende uma decisão judicial imediata, sob pena de se causar possíveis danos irreparáveis aos jurisdicionados.

O novo CPC traz à baila uma cláusula geral denominada 'Tutelas Provisórias', no livro V da parte geral, nos artigos 294 a 311, das quais se incluem as tutelas de urgência (cautelar e antecipada) e as de evidência, o que merece uma análise mais detalhada.

As tutelas de urgência subdividem-se em cautelar ou antecipada, que poderão ser concedidas em caráter antecedente ou incidental. Não houve qualquer alteração na caracterização dos institutos, mantendo-se a essência de satisfatividade nos pedidos de tutela antecipada e de instrumentalidade nos cautelares, sendo verídica a fungibilidade entre elas, consoante o disposto no parágrafo único do art. 305. Contudo, no que tange ao procedimento para a formulação em juízo, considerável mudança foi verificada.

Cumpre destacar que inexiste atualmente a necessidade de ajuizamento de duas demandas em caso de pedido cautelar antecedente à demanda principal, devendo o autor apenas aditar seu pedido principal a este cautelar anterior (artigos 305 a 310), podendo, outrossim, formulá-lo em caráter incidental, por simples petição no curso da demanda, sem a necessidade de pagamento de despesas adicionais (artigos 294 e 295), ou através de pedido cumulado na própria peça vestibular (artigos 300 a 302).

Já a tutela antecipada, que se trata do próprio pedido principal da demanda, poderá ser formulada de forma antecedente (artigos 303 e 304); ou na petição inicial (artigos 294 e 295), destacando que sua alteração ou formulação a posteriori, submeter-se-á às regras processuais válidas para alteração do pedido ou causa de pedir, dispostas no art. 329.

É interessante notar uma considerável alteração legislativa no que tange ao pedido de tutela antecipada antecedente, como mecanismo apto para a obtenção de uma medida de urgência, pelo que a lei exige apenas a exposição da lide, do direito que se busca realizar, bem como, a narrativa do perigo de dano ou risco ao resultado útil do processo, na qual o autor poderá aditar a petição inicial para a formulação de outro(s) pedido(s) principal(is). 
É possível, ainda, que o requerente não tenha interesse na propositura de uma demanda principal, limitando seu pedido a esta tutela antecedente que, se deferida, pode não ser obstada pelo demandado e tornar-se estável, na forma do artigo 304. A referida estabilidade pode ser revista, reformada ou invalidada por qualquer das partes, no prazo de dois anos, mas a mesma não sofre os efeitos da coisa julgada.

Ante as considerações supra, é forçoso admitir que se tenha na separação, como causa de pedir, algum fundamento relevante que justifique o pedido de uma tutela provisória, inclusive a própria separação de corpos e/ou afastamento do outro cônjuge do lar, hipótese em que poderá ser requerida, de acordo com as novas regras processuais, como tutela antecipada ou cautelar, mediante outro pedido na peça vestibular em conjunto com o principal, ou por intermédio de medida antecedente. Há que se notar que, se houver intenção na estabilização da tutela, haverá a necessidade de formulação do pedido antecedente na forma dos artigos 303 e 304 , não se podendo valer da cautelar, eis que inexiste tal previsão legal.

Por fim, é preciso esclarecer o que se trata de tutela de evidência, destacando desde já que a própria expressão evidencia a relativa certeza que detém o julgador para antecipar o provimento final, baseado em prova documental, tese firmada em julgamento de recursos repetitivos e/ou para evitar delongas desnecessárias, objetivando garantir celeridade, efetividade e integração da decisão no caso concreto ao ordenamento jurídico, independentemente de perigo de dano ou risco ao resultado útil do processo, na exata forma do artigo 311.

Destarte, podem-se perceber algumas situações em que o juiz poderá julgar com fulcro na evidência nas demandas de separação, $v$.g., se perceber que seu motivo é apenas a divisão patrimonial, e a prova for incontroversa, poderá julgar esta demanda, na forma do art. 311, IV, fixando o marco inicial da separação e a partilha de bens.

\subsection{COLABORAÇÃO PROCESSUAL}

Outra medida importante que poderá ser tomada pelo juiz ao receber uma ação de separação judicial, consiste no seu dever de incentivar a atividade cooperada das partes, na exata forma do artigo $6^{\circ}$ do $\mathrm{CPC}^{31}$, o que também poderá ser obtida por meio da designação da aludida audiência inaugural do procedimento.

${ }^{31}$ Art. 6o Todos os sujeitos do processo devem cooperar entre si para que se obtenha, em tempo razoável, decisão de mérito justa e efetiva. 
Não é demasiado lembrar que o artigo $357, \S 3^{\circ}$ do novo CPC $^{32}$ incentiva esta conduta cooperativa do magistrado na colheita de provas, em especial quando se trata de matéria de alta complexidade, como as verificadas nas demandas de família, competindo-lhe criar mecanismos processuais que justifiquem tal desiderato.

Por esta razão, não se verifica qualquer óbice na designação na audiência vestibular do procedimento, hipótese em que o juiz atuará como incentivador da atividade cooperada das partes, ora encaminhando-as para sessões de mediação e/ ou conciliação, judiciais ou extrajudiciais com profissionais que elas possam escolher; ora nomeando experts (psicólogos, assistentes sociais, colaboradores etc.) para condução apropriada do litígio, se perceber que o alto grau de litigiosidade não possibilitará a devida solução.

Nestes casos, poderá por meio da flexibilização procedimental suso proposta, determinar a conversão do procedimento para colheita de provas com auxílio de perito do juízo em conjunto com outros profissionais de confiança das partes, sem prejuízo de designação de novas audiências para avaliações futuras da situação em apreço.

Frise-se que todas estas medidas deverão ser tomadas com conjunto com as partes, as quais lhes serão expostos conhecimentos acerca dos procedimentos aplicados e/ou respectivas técnicas, para uma solução a contento de suas causas.

Tais medidas podem e devem ser verificadas em quaisquer demandas de família, não se furtando sua aplicação às demandas de separação, ora em análise. Ademais, o magistrado pode verificar que o conflito envolve não só questões patrimoniais, mas também desavenças de caráter existencial, inclusive envolvendo interesses de menores, hipótese em que estas medidas serão ainda mais importantes de serem tomadas para evitar potencialização dos inequívocos prejuízos já sofridos pelas partes.

Esta é a tônica do novo CPC, competindo ao magistrado em juízo de conveniência e oportunidade, perseguir a busca de uma solução ideal para os complexos conflitos familiares, em especial em atividade cooperada, o que é ratificado pelos artigos 190 e $191^{33}$.

\footnotetext{
${ }^{32}$ Art. 357. Não ocorrendo nenhuma das hipóteses deste Capítulo, deverá o juiz, em decisão de saneamento e de organização do processo: [...] $\S 3^{\circ}$ Se a causa apresentar complexidade em matéria de fato ou de direito, deverá o juiz designar audiência para que o saneamento seja feito em cooperação com as partes, oportunidade em que o juiz, se for o caso, convidará as partes a integrar ou esclarecer suas alegações.

33 Art. 190. Versando o processo sobre direitos que admitam autocomposição, é lícito às partes plenamente capazes estipular mudanças no procedimento para ajustá-lo às especificidades da causa e convencionar sobre os seus ônus, poderes, faculdades e deveres processuais, antes ou durante o processo.

Parágrafo único. De ofício ou a requerimento, o juiz controlará a validade das convenções previstas neste artigo, recusando-lhes aplicação somente nos casos de nulidade ou de inserção abusiva em contrato de adesão ou em que alguma parte se encontre em manifesta situação de vulnerabilidade.

Art. 191. De comum acordo, o juiz e as partes podem fixar calendário para a prática dos atos processuais, quando for o caso.
} 


\section{CONCLUSÃO}

Os precedentes em voga trazem à tona a rediscussão acerca do cabimento ou não das demandas de separação judicial no ordenamento brasileiro, após o advento da EC 66/2010, visto que instituiu a possibilidade do divórcio direto sem qualquer requisito temporal ou discussão de culpa, bastando a falta de amor e/ou afeto como requisito para a dissolução do casamento.

É forçoso concluir que mesmo que os cônjuges queiram um "prazo de reflexão" para amadurecer a ideia do rompimento definitivo do vínculo conjugal, o instituto da separação judicial (consensual ou litigiosa) ainda seria desnecessário, uma vez que tanto a separação de fato, quanto a separação de corpos, serviriam para proteger os interesses envolvidos, eis que suspendem os deveres do casamento e finalizam a comunicabilidade dos bens. Em consequência, poderiam decorrer duas situações: a reconciliação do casal, restabelecendo o vínculo anterior, o que não precisaria sequer de pedido de revogação em caso de separação de corpos; e, a possibilidade de se formular o pedido de divórcio direto, caso entendam pelo inevitável fim do relacionamento.

No entanto, com base nos precedentes sub examine, valendo-se do método de abordagem indutivo, em que pese ainda estarem pendentes de ratificação ou não pelo Supremo Tribunal Federal, restou encampado o instituto da separação como veículo processual apto a ser perquirido por intermédio de ação judicial.

Neste jaez, cumpre aos órgãos judiciais encontrar um mecanismo para adequá-lo à atuais vertentes processuais, de modo que seja possível garantir maior efetividade aos jurisdicionados, sendo vedada sua rejeição, sob pena de afronta não só à celeridade e à efetividade, como também aos preceitos de estabilidade, coerência e integridade que são talhados pelo novel CPC.

Por estas razões, são trazidas à tona algumas sugestões práticas que possam garantir o recebimento destas demandas de separação judicial, pelo magistrado, conduzindo-as para uma solução satisfatória, evitando os indesejáveis atos decisórios desprovidos de efetividade que só emperram e desprestigiam a prestação jurisdicional. Vejamos: a designação de audiência inaugural com as partes e o juiz togado que, na qualidade de gestor do processo, terá o condão de obter a real intenção na aludida demanda, podendo determinar a conversão do procedimento em divórcio, se perceber que se trata de discussão patrimonial, definindo data da separação de fato e possíveis bens a serem partilhados, se não houver necessidade de produção de outras provas; sem prejuízo, será possível, neste ato, analisar os pedidos de tu- 
telas provisórias, inclusive fazendo às vezes de audiência de justificação; poderá determinar o encaminhamento das partes para sessão de mediação se perceber que os mesmos precisam de um "prazo de reflexão" para amadurecimento acerca da certeza sobre o fim do relacionamento; e, ainda, realizar atividade cooperada com as partes para apuração de provas, de acordo com o grau de litigiosidade da demanda; ou, determinar uma possível inversão procedimental caso perceba necessária ao deslinde da controvérsia, com base no princípio da eficiência, objetivando obter o máximo de elementos (defesa, provas etc.) para evitar o ajuizamento de outra demanda futura, inclusive com incentivos constantes de conciliação.

É forçoso concluir que com este "novo olhar" da magistratura sobre estas demandas, aplicando-se os mecanismos processuais existentes na nova lei, uma melhor prestação jurisdicional será realizada e os conflitos solucionados de uma forma muito mais propícia às suas peculiaridades.

\section{REFERÊNCIAS}

BONAVIDES, Paulo. Curso de direito constitucional. 12. ed. São Paulo: Malheiros, 2002.

CAHALI, Yussef Said. Divórcio e Separação. 11. ed. São Paulo: Revista dos Tribunais, 2005.

CASTRO, Guilherme Couto. Direito Civil lições. Niterói: Impetus, 2007.

CUNHA, Leonardo Carneiro da. A previsão do princípio da eficiência no projeto do novo Código de Processo Civil brasileiro. 2014. Disponível em: <http:// www.academia.edu/9253169/A_previs\%C3\%A30_do_princ\%C3\%ADpio_da_efici\%C3\%AAncia_no_projeto_do_novo_C\%C3\%B3digo_de_Processo_Civil_brasileiro > . Acesso 10 abr 2017.

DIAS, Maria Berenice. Manual de Direito das Famílias. 9. ed. São Paulo: Revista dos Tribunais, 2013.

MADALENO, Rolf. Curso de Direito de Família. 4. ed. Rio de Janeiro: Forense, 2011. 
MEDINA, Valéria Julião Silva. Processo de Família e o novo CPC. Curitiba: Juruá, 2017.

PENA JR., Moacir César. Direito das pessoas e das famílias: doutrina e jurisprudência. São Paulo: Saraiva, 2008.

PEREIRA, Rodrigo da Cunha. Divórcio: Teoria e Prática. 4. ed. São Paulo: Saraiva, 2013.

SILVA, Ovídio A. Baptista da. Do Processo Cautelar. 3. ed. Rio de Janeiro: Forense, 2001.

SILVA, Regina Beatriz Tavares da. A Culpa nas relações de família. In: DELGADO, Mário Luiz; ALVES, Jones Figueiredo (Org.). Questões Controvertidas no Direito de Família e das Sucessões. São Paulo: Método, 2005.

Recebido em: 08 de novembro de 2017 Aceito em: 24 de julbo de 2018 